\title{
Colonic stricture with filiform polyposis in Crohn's disease
}

\author{
Akira Hokama, ${ }^{1}$ Masayoshi Nagahama, ${ }^{2}$ Kazuto Kishimoto, ${ }^{3}$ Jiro Fujita ${ }^{3}$
}

\begin{abstract}
${ }^{1}$ Department of Endoscopy, University of the Ryukyus, Nishihara, Japan ${ }^{2}$ Department of Digestive and General Surgery, University of the Ryukyus, Nishihara, Japan ${ }^{3}$ Department of Infectious, Respiratory, and Digestive Medicine, University of the Ryukyus, Nishihara, Japan
\end{abstract}

\section{Correspondence to}

Professor Akira Hokama, hokama-a@med.u-ryukyu.ac.jp

Accepted 16 April 2014
CrossMark

\begin{tabular}{|l|}
\hline To cite: Hokama A, \\
Nagahama M, Kishimoto K, \\
et al. BMJ Case Rep \\
Published online: [please \\
include Day Month Year] \\
doi:10.1136/bcr-2014- \\
204710 \\
\hline
\end{tabular}

\section{DESCRIPTION}

A 41-year-old man with a 5-year history of Crohn's disease presented with abdominal distention, right lower quadrant pain and weight loss for 4 weeks. On physical examination, the abdomen was distended with right lower quadrant tenderness. Plain radiograph of the abdomen disclosed marked dilation of the ascending colon due to a stricture at the hepatic flexure and intraluminal polypoid filling defects that suggested the presence of postinflammatory polyps (figure 1). Colonoscopy failed to disclose the precise cause of the stricture. CT scan could not rule out neoplasms at the stricture. $\mathrm{He}$ thus underwent right hemicolectomy. Gross examination showed a colonic stricture with filiform polyposis at the hepatic flexure and the ileocaecal region (figure 2). Only oedematous fine holds were noted on the dilated ascending colon. Pathological examination confirmed no evidence of calcification, adenoma or adenocarcinoma. The postoperative course was uneventful and he remains well.

Filiform polyposis is an uncommon entity characterised by numerous slender and finger-like polyps. It is usually associated with a history of ulcerative colitis, Crohn's disease and intestinal tuberculosis. Filiform polyposis develops as a postinflammatory reparative process in response to the

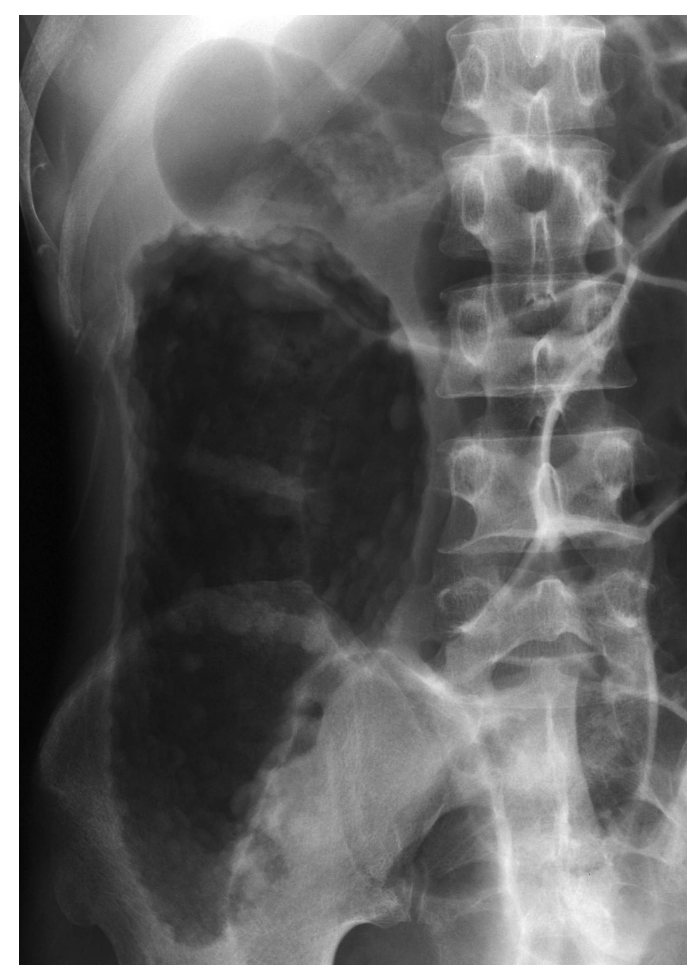

Figure 1 Plain radiograph of the abdomen disclosing marked dilation of the ascending colon due to a stricture at the hepatic flexure and intraluminal polypoid filling defects.

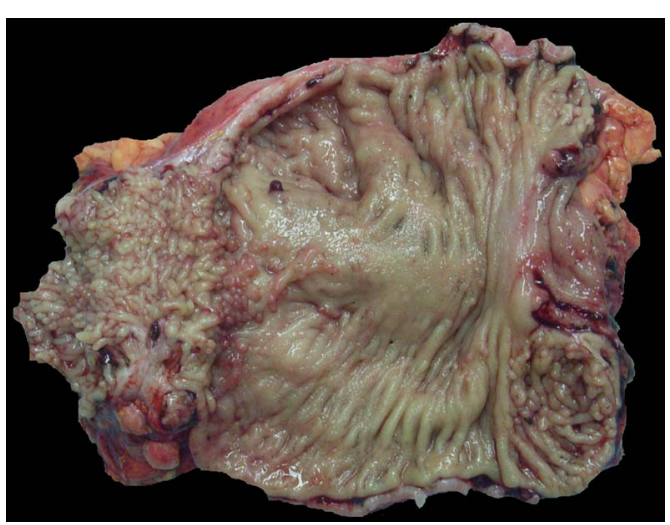

Figure 2 Surgical specimen showing a colonic stricture with filiform polyposis at the hepatic flexure and the ileocaecal region and oedematous fine holds on the dilated ascending colon.

altering ulceration and healing cycles during chronic luminal inflammation. ${ }^{1}$ Filiform polyposis itself is not considered precancerous and thus does not require surgical resection except in complications including bowel obstruction, ${ }^{2}$ as in this case.

\section{Learning points}

- Filiform polyposis is an uncommon entity characterised by numerous slender and finger-like polyps and is associated with a history of inflammatory bowel disease.

- Filiform polyposis itself is not considered precancerous and thus may require surgical resection only in complications, such as bowel obstruction.

- When a patient is affected by inflammatory bowel disease and a colonic stricture with filiform polyposis, it should be considered as a first hypothesis in a postinflammatory reparative process and not immediately as an advanced colon cancer.

Contributors $A H, M N$ and $K K$ treated the patient. $A H$ wrote the paper. JF supervised the study.

Competing interests None.

Patient consent Obtained.

Provenance and peer review Not commissioned; externally peer reviewed.

\section{REFERENCES}

1 Lim YJ, Choi JH, Yang CH. What is the clinical relevance of filiform polyposis? Gut Liver 2012;6:524-6.

2 Maggs JR, Browning LC, Warren BF, et al. Obstructing giant post-inflammatory polyposis in ulcerative colitis: case report and review of the literature. J Crohns Colitis 2008:2:170-80. 


\section{Images in...}

Copyright 2014 BMJ Publishing Group. All rights reserved. For permission to reuse any of this content visit http://group.bmj.com/group/rights-licensing/permissions.

BMJ Case Report Fellows may re-use this article for personal use and teaching without any further permission.

Become a Fellow of BMJ Case Reports today and you can:

- Submit as many cases as you like

- Enjoy fast sympathetic peer review and rapid publication of accepted articles

- Access all the published articles

- Re-use any of the published material for personal use and teaching without further permission

For information on Institutional Fellowships contact consortiasales@bmjgroup.com

Visit casereports.bmj.com for more articles like this and to become a Fellow 